\title{
PENGARUH KEPEMIMPINAN, KOMPENSASI FINANSIAL DAN DISIPLIN KERJA TERHADAP KEPUASAN KERJA KARYAWAN PADA HOTEL LE MERIDIEN BALI JIMBARAN
}

\author{
Ni Putu Jenia Hayuningsih ${ }^{1}$ I Made Setena $^{2}$ I.A Cynthia Saisaria Mandasari ${ }^{3}$ \\ Fakultas Ekonomi dan Bisnis Universitas Warmadewa, Denpasar, Bali-Indonesia \\ *jenia.hayuningsih05@gmail.com
}

\begin{abstract}
The development of the industrial world in the era of globalization, is felt increasingly rapidly influenced by changes in transportation technology, information and production processes and computer applications in various aspects of business. And requires the company to achieve its goals at least can be obtained from employee job satisfaction, for that several factors that influence it are leadership, financial compensation and work discipline. In this study using a saturated sample technique with a total sample of 99 people. Data collection using a Likert scale questionnaire 5. The formulation of the problem in this study are: What is the effect of leadership on employee job satisfaction at Le Meridien Bali Jimbaran Hotel, What is the effect of financial compensation on employee job satisfaction at Le Meridien Bali Jimbaran Hotel, What is the effect of work discipline on satisfaction employee work at Le Meridien Bali Jimbaran Hotel, How is the influence of leadership, financial compensation and work discipline on employee job satisfaction at Le Meridien Bali Jimbaran Hotel. The purpose of this study is to analyze the effect of leadership, financial compensation and work discipline on job satisfaction of Le Meridien Hotel employees Bali Jimbaran. using a questionnaire research instrument with 5 Likert scale. The research instrument was tested for validity and reliability which gave a correlation of $>0.3$ and Alpha cranbach $>0.60$ so it was feasible to use. The research instrument has fulfilled the classical assumption test that is the test for normality, multicollinearity and heteroscedasticity. From the results of multiple linear regression analysis obtained by the equation: $Y=4.553+0.350 X 1+0.229 X 2+0.320 X_{3}$. Based on the F Test obtained F-count 15.289> F-table $\neg 2.29$ with a significance value of 0,000 $<0.05$ which means there is indeed a positive and significant effect between leadership, financial compensation and work discipline on employee job satisfaction at Le Meridien Bali Jimbaran Hotel and obtained not by accident. T test for the influence of leadership on employee job satisfaction obtained t-count 4.117> t-table 1.985 with a significance level of 0,000 $<0.05$ which means that leadership has a positive and significant effect on employee job satisfaction at Le Meridien Bali Jimbaran Hotel. T test for the effect of financial compensation on employee job satisfaction obtained t-count 2.532> t-table 1.985 with a significance level of $0.013<0.05$ which means financial compensation has a positive and significant effect on employee job satisfaction at Le Meridien Bali Jimbaran Hotel. T test for the effect of work discipline on employee job satisfaction obtained t-test $3.530>$ t-table 1.985 with a significance level of $0.001<0.05$ which means that work discipline has a positive and significant effect on employee job satisfaction at Le Meridien Bali Jimbaran Hotel. Variables that have an influence dominant is leadership. The conclusion of this research is leadership, financial compensation and work discipline have an important role both individually and together in increasing job satisfaction.
\end{abstract}

Keywords: Leadership, Financial Compensation, Work Discipline, and Job Satisfaction

\begin{abstract}
Abstrak
Perkembangan dunia industri dalam era globalisasi, dirasakan semakin pesat yang dipengaruhi oleh adanya perubahan teknologi transportasi, informasi dan proses produksi serta aplikasi komputer dalam berbagai aspek bisnis. Dan mengharuskan perusahaan dalam mencapai tujuannya setidaknya dapat diperoleh dari kepuasan kerja karyawan, untuk itu beberapa faktor yang mempengaruhinya adalah kepemimpinan, kompensasi finansial serta disiplin kerja. Pada penelitian ini menggunakan teknik sampel jenuh dengan jumlah sampel sebanyak 99 orang. Pengumpulan data menggunakan kuesioner skala likert 5. Perumusan masalah dalam penelitian ini adalah : Bagaimanakah pengaruh
\end{abstract}


kepemimpinan terhadap kepuasan kerja karyawan pada Hotel Le Meridien Bali Jimbaran, Bagaimanakah pengaruh kompensasi finansial terhadap kepuasan kerja karyawan pada Hotel Le Meridien Bali Jimbaran, Bagaimanakah pengaruh disiplin kerja terhadap kepuasan kerja karyawan pada Hotel Le Meridien Bali Jimbaran, Bagaimanakah pengaruh kepemimpinan, kompensasi finansial dan disiplin kerja terhadap kepuasan kerja karyawan pada Hotel Le Meridien Bali Jimbaran.Tujuan penelitian ini adalah untuk menganalisis pengaruh kepemimpinan, kompensasi finansial dan disiplin kerja terhadap kepuasan kerja karyawan Hotel Le Meridien Bali Jimbaran. menggunakan instrumen penelitian kuisioner dengan 5 skala likert. Instrumen penelitian telah diuji validitas dan reliabilitas yang memberi hasil korelasi > 0,3 dan Alpha cranbach > 0,60 sehingga layak untuk digunakan. Instrumen penelitian telah memenuhi uji asumsi klasik yaitu uji normalitas, multikolinieritas dan heteroskedastisitas. Dari hasil analisis regresi linier berganda diperoleh persamaan : $\mathrm{Y}=4,553+0,350 \mathrm{X}_{1}+0,229 \mathrm{X}_{2}+0,320 \mathrm{X}_{3}$. Berdasarkan Uji F diperoleh $\mathrm{F}_{\text {-hitung }} 15,289$ $>F_{\text {-tabel }} 2,29$ dengan nilai signifikansi $0,000<0,05$ yang berarti memang ada pengaruh positif dan signifikan antara kepemimpinan, kompensasi finansial dan disiplin kerja terhadap kepuasan kerja karyawan pada Hotel Le Meridien Bali Jimbaran dan diperoleh bukan secara kebetulan. Uji t untuk pengaruh kepemimpinan terhadap kepuasan kerja karyawan diperoleh $t_{\text {-hitung }} 4,117>t_{\text {-tabel }} 1,985$ dengan tingkat signifikansi sebesar $0,000<0,05$ yang berarti kepemimpinan berpengaruh positif dan signifikan terhadap kepuasan kerja karyawan Hotel Le Meridien Bali Jimbaran. Uji t untuk pengaruh kompensasi finansial terhadap kepuasan kerja karyawan diperoleh $\mathrm{t}_{\text {-hitung }} 2,532>\mathrm{t}_{\text {tabel }}$ 1,985 dengan tingkat signifikansi $0,013<0,05$ yang berarti kompensasi finansial berpengaruh positif dan signifikan terhadap kepuasan kerja karyawan Hotel Le Meridien Bali Jimbaran. Uji t untuk pengaruh disiplin kerja terhadap kepuasan kerja karyawan diperoleh $t_{\text {-hitung }} 3,530>t_{\text {tabel }} 1,985$ dengan tingkat signifikansi 0,001 < 0,05 yang berarti disiplin kerja berpengaruh positif dan signifikan terhadap kepuasan kerja karyawan Hotel Le Meridien Bali Jimbaran. Variabel yang memiliki pengaruh dominan adalah kepemimpinan. Kesimpulan dari penelitian ini adalah kepemimpinan, kompensasi finansial dan disiplin kerja memiliki peran penting baik secara individu maupun bersama- sama dalam meningkatkan kepuasan kerja.

Kata Kunci : Kepemimpinan, Kompensasi Finansial, Disiplin Kerja, dan Kepuasan Kerja

\section{A. PENDAHULUAN}

Perkembangan dunia industri dalam era globalisasi, dirasakan semakin pesat yang dipengaruhi oleh adanya perubahan teknologi transportasi, informasi dan proses produksi serta aplikasi komputer dalam berbagai aspek bisnis semakin luas. Bisnis pariwisata yang dikenal sebagai industri pariwisata telah menjadi tumpuan pembangunan daerah Pulau Bali. Pulau Bali yang dikenal sebagai daerah tujuan wisata dunia terutama berkat aspek budaya yang mencatat kunjungan wisatawannya dari wisatawan asing maupun lokal.

Keberadaan sumber daya manusia yang handal memiliki peran yang lebih penting dibandingkan dengan sumber daya yang lainnya. Elemen sumber daya manusia merupakan jantung bagi perusahaan. Sumber daya manusia adalah harta yang paling penting yang dimiliki oleh suatu perusahaan atau organisasi, sedangkan manajemen yang efektif adalah kunci bagi keberhasilan suatu perusahaan dan organisasi tersebut.

Kepuasan kerja pada umumnya merupakan hal yang bersifat individual, setiap individual memiliki tingkat kepuasan kerja yang berbeda-beda sesuai dengan keinginan dan sistem nilai yang dianutnya. Kepuasan kerja para karyawan sangat penting dan besar pengaruhnya dalam kemajuan perusahaan, karena bisa mempengaruhi berbagai kegiatan perusahaan. Perusahaan harus mengetahui apa saja yang menyebabkan puas atau tidaknya seorang karyawan yang bekerja didalam perusahaan tersebut 
Menurut (Feriyanto \& Shyta Triana, 2015:94) kepemimpinan merupakan kemampuan mempengaruhi orang lain, bawahan atau kelompok, kemampuan mengarahkan tingkah laku bawahan atau kelompok, memiliki kemapuan atau keahlian khusus dalam bidang yang diinginkan oleh kelompoknya, untuk mencapai tujuan organisasi atau kelompok. Masalah dalam hal kepemimpinan pada Hotel Le Meridien Bali Jimbaran, dimana terjadi ketidak sesuaian antara konsep teori kepemimpinan dengan gambaran kenyataaan di perusahaan, antara lain :

1. Pimpinan kurang berani menerapkan konsep dan prosedur kerja yang baru dalam menyelesaikan masalah, padahal konsep dan prosedur kerja yang dijalankan selama ini dirasakan sudah tidak

2. sesuai dengan situasi dan kondisi yang ada.

3. Pimpinan lebih sering memberikan tugas tertentu kepada beberapa orang karyawan yang dipercayainya, walaupun ada karyawan lain yang punya kemampuan memadai dalam menyelesaikan tugas yang diberikan. Pimpinan jarang mengakui dan menghargai kerja karyawan secara terbuka, walaupun kinerjanya baik dan mampu memenuhi target.

4. Pimpinan juga tidak bisa menyatakan visi dan misi yang jelas dan menarik kepada karyawan, pimpinan juga kurang melaksanakan visi tersebut dan juga pimpinan kurang memiliki rasa kepercayaan kepada karyawannya, yang menyebabkan turunnya tingkat kepuasan kerja karyawan.

Suatu cara perusahaan meningkatkan kepuasan kerja adalah melalui kompensasi.

Masalah-masalah kompensasi mungkin merupakan fungsi manajemen personalia yang paling sulit dan membingungkan, tidak hanya karena pemberian kompensasi merupakan salah satu tugas yang paling komfleks, tetapi juga salah satu aspek yang paling berarti baik bagi karyawan maupun organisasi. Kompensasi merupakan semua pendapatan yang berbentuk uang, barang langsung atau tidak langung yang diterima karyawan sebagai imbalan atas jasa yang diberikan kepada perusahaan (Afandi P, 2018:191). Hotel Le Meridien Bali Jimbaran maka dapat dijabarkan beberapa hal yang tidak sesuai yang terjadi diperusahaan antara lain :

1. Waktu pembayaran gaji yang sering mengalami keterlambatan dari waktu yang seharusnya.

2. Kurangnya tunjangan transport dan jaminan kesehatan (BPJS) masih ditanggung oleh karyawan sendiri.

Menurut (Afandi P, 2018:78) Disiplin kerja merupakan suatu alat yang digunakan para manajer untuk mengubah suatu perilaku serta sebagai suatu upaya untuk meningkatkan kesadaran dan kesediaan seseorang mentaati semua peraturan perusahaan dan norma-norma sosial yang berlaku. Adapun masalah disiplin kerja yang terjadi pada Hotel Le Meridien Bali Jimbaran yaitu :

1. Karyawan masih terlambat datang kerja.

2. Karyawan menggunakan jam kerja istirahat melebihi batas waktu yang sudah di tentuksn oleh perusahaan.

3. Kurangnya semangat kerja karyawan.

Kepuasan kerja merupakan perasaan senang atau tidak senang dalam memandang atau menjalankan pekerjaannya. Apabila seseorang merasa senang terhadap pekerjaannya maka orang tersebut dapat dikatakan puas terhadap 
pekerjaannya maka orang tersebut dapat dikatakan puas terhadap pekerjaannya. Reaksi positif dan negative terlihat pada karyawan tergantung dari kepuasan kerja yang mereka dapatkan (Afandi P, 2018:75).

Data berikut memberikan informasi mengenai jumlah karyawan dan tingkat absensi karyawan pada Hotel Le Meridien Bali Jimbaran yang dapat mencerminkan tingkat kepuasan kerja karyawan.

\begin{tabular}{|c|c|c|c|c|c|c|}
\hline \multicolumn{7}{|c|}{$\begin{array}{c}\text { Tabel 3 } \\
\text { Jumlah Karyawan dan Tingkat Absensi } \\
\text { Hotel Le Meridien Bali Jimbaran } \\
\text { Periode Januari-Desember } 2018 \\
\end{array}$} \\
\hline Bulan & $\begin{array}{c}\text { Jumlah } \\
\text { Karyawan } \\
\text { (Orang) }\end{array}$ & $\begin{array}{c}\text { Hari } \\
\text { Kerja } \\
\text { (Hari) }\end{array}$ & $\begin{array}{c}\text { Hari Kerja } \\
\text { Seharusnya } \\
\text { (Hari) }\end{array}$ & $\begin{array}{c}\text { Hari Kerja } \\
\text { yang hilang } \\
\text { (Hari) }\end{array}$ & $\begin{array}{c}\text { Hari Kerja } \\
\text { Senyatanya } \\
\text { (Hari) }\end{array}$ & $\begin{array}{c}\text { Prosentase } \\
\text { Absensi } \\
(\%)\end{array}$ \\
\hline $\mathrm{A}$ & B & $\mathrm{C}$ & $\mathrm{D}=\mathrm{BxC}$ & $\mathrm{E}$ & $\mathrm{F}=\mathrm{D}-\mathrm{E}$ & $\mathrm{G}=\mathrm{E} / \mathrm{D} \times 100 \%$ \\
\hline Januari & 100 & 24 & 2.400 & 9 & 2.391 & 0,37 \\
\hline Februari & 100 & 20 & 2.000 & 8 & 1.992 & 0,4 \\
\hline Maret & 100 & 21 & 2.100 & 9 & 2.091 & 0,43 \\
\hline April & 100 & 22 & 2.200 & 10 & 2.190 & 0,45 \\
\hline Mei & 100 & 23 & 2.300 & 9 & 2.291 & 0,40 \\
\hline Juni & 100 & 20 & 2.000 & 10 & 1.990 & 0,5 \\
\hline Juli & 100 & 23 & 2.300 & 8 & 2.292 & 0,35 \\
\hline Agustus & 100 & 22 & 2.200 & 9 & 2.191 & 0,41 \\
\hline September & 100 & 21 & 2.100 & 10 & 2.090 & 0,48 \\
\hline Oktober & 100 & 23 & 2.300 & 8 & 2.292 & 0,35 \\
\hline Nopember & 100 & 21 & 2.100 & 8 & 2.092 & 0,38 \\
\hline Desember & 100 & 22 & 2.200 & 10 & 2.190 & 0,45 \\
\hline Jumlah & & 262 & 26.200 & 108 & 26.092 & 4,97 \\
\hline Rata-rata & & 21,83 & 2.183 .33 & 9 & $2.174,3$ & 0,41 \\
\hline
\end{tabular}

Berdasarkan tabel 3 diatas dapat diketahui bahwa rata-rata tingkat absensi karyawan pada Hotel Le Meridien Bali Jimbaran dari bulan Januari 2018 sampai bulan Desember 2018 adalah sebesar 0,41\%, ini berarti bahwa tingkat absensi karyawan tergolong rendah karena tingkat absensi yang tinggi diatas 3\%, dibawah 3 sampai 0\% dianggap rendah Mudiartha dalam (Sudarmini, K., dan Putu, 2018:6).

Berdasarkan latar belakang masalah tersebut di atas, maka perlu diadakan penelitian tentang "Pengaruh Kepemimpinan, Kompensasi Finansial dan Disiplin Kerja Terhadap Kepuasan Kerja Karyawan pada Hotel Le Meridien Bali Jimbaran"

1. Bagaimanakah pengaruh kepemimpinan terhadap kepuasan kerja karyawan pada Hotel Le Meridien Bali Jimbaran?

2. Bagaimanakah pengaruh kompensasi finansial terhadap kepuasan kerja karyawan pada Hotel Le Meridien Bali Jimbaran?

3. Bagaimanakah pengaruh disiplin kerja terhadap kepuasan kerja karyawan pada Hotel Le Meridien Bali Jimbaran?

4. Bagaimanakah pengaruh kepemimpinan, kompensasi finansial dan disiplin kerja terhadap kepuasan kerja karyawan pada Hotel Le Meridien Bali Jimbaran?

\section{B. TINJAUAN PUSTAKA}

\section{Manajemen Sumber Daya Manusia}

Manajemen sumber daya manusia merupakan sebagai ilmu dan seni dalam melakukan tindakan perencanaan, pengorganisasian, penggerakan, penyusunan personalia dan pengendalian secara terarah melalui pemanfaatan sumber daya manusia dan sumber daya lainnya dalam mencapai suatu tujuan tertentu (Afandi $\mathrm{P}$, $\underline{2018: 1)}$ 


\section{Fungsi Manajemen Sumber Daya Manusia}

Adapun fungsi manajemen sumber daya manusia dalam perusahaan menurut (Sutrisno, 2017:9-11), terdiri dari : Perencanaan, Pengorganisasian, Pengarahan dan Pengadaan, Pengendalian, Pengembangan, Kompensasi, Pengintegrasian, Pemeliharaan, Kedisiplinan, Pemberhentsian.

\section{Kepemimpinan}

Kepemimpinan merupakan kemampuan mempengaruhi orang lain, bawaha atau kelompok, kemampuan mengarahkan tingkah laku bawahan atau kelompok, memiliki kemapuan atau keahlian khusus dalam bidang yang diinginkan oleh kelompoknya, untuk mencapai tujuan organisasi atau kelompok (Feriyanto \& Shyta Triana, 2015:94).

Tipe - Tipe Kepemimpinan

Adapun tiga tipe kepemimpinan menurut (Afandi P, 2018:73) yaitu sebagai berikut

\section{Kompensasi}

a) Kepemimpinan otoriter.

b) Kepemimpinan Demokrasi

c) Kepemimpinan Laissez-Faire.

Kompensasi adalah penghargaan atau imbalan langsung maupun tidak langsung, finansial maupun non finansial yang adil, dan layak kepada karyawan, sebagai balasan atas kontribusi/jasanya terhadap pencapaian tujuan organisasi (Marwansyah, 2014:269).

Jenis-Jenis Kompensasi

Adapun jenis-jenis kompensasi adalah sebagai berikut :

1) Kompensasi Finansial

Kompensasi finansial dibagi menjadi dua bagian, yaitu kompensasi finansial yang dibayarkan secara langsung seperti gaji, upah, komisi dan bonus. Kompensasi finansial yang diberikan secara tidak langsung seperti tunjangan kesehatan, tunjangan pensiun, tunjangan hari raya, tunjangan perumahan, tunjangan pendidikan dan lain sebagainya.

2) Kompensasi Non Finansial

Pada kompensasi non finansial mencangkup berbagai bentuk kepuasan yang diterima oleh seseorang dari pekerjaan itu sendiri, atau yang berupa lingkungan psikologis dan atau lingkungan fisik tempat seseorang bekerja (Marwansyah, 2014:276).

Indikator Kompensasi

Indikator-indikator kompensasi menurut (Afandi P, 2018:194-195), yaitu:

1) Gaji.

2) Insentif.

3) Tunjangan.

4) Fasilitas.

\section{Disiplin Kerja}

Disiplin kerja adalah suatu alat yang digunakan para manajer untuk mengubah suatu perilaku serta sebagai suatu upaya untuk meningkatkan kesadaran dan kesediaan seseorang mentaati semua peraturan perusahaan dan norma-norma sosial yang berlaku (Afandi P, 2018:78) 


\section{Kerangka Pemikiran}

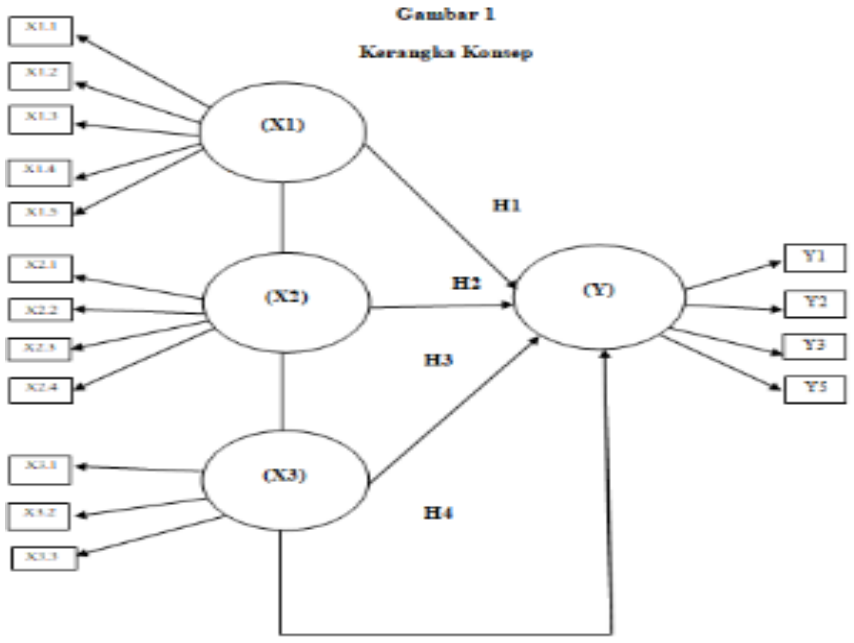

\section{Hipotesis}

H1 : Kepemimpinan berpengaruh positif dan signifikan terhadap kepuasan kerja karyawan.

H2 : Kompensasi Finansial berpengaruh positif dan signifikan terhadap kepuasan kerja karyawan.

H3 : Disiplin Kerja berpengaruh positif dan signifikan terhadap kepuasan kerja karyawan.

H4 : Kepemimpinan, kompensasi finansial, dan disiplin kerja secara simultan berpengaruh positif dan signifikan terhadap kepuasan kerja karyawan.

\section{METODE PENELITIAN}

\section{Tempat dan Obyek Penelitian}

1. Penelitian ini dilakukan pada pada Hotel Le Meridien Bali Jimbaran yang beralamat di Jalan Bukit Permai, Jimbaran, Kec.Kuta Selatan. Kabupaten Badung, Bali 80361.

2. Yang menjadi obyek penelitian adalah bidang manajemen sumber daya manusia yaitu kepemimpinan, kompensasi finansial dan disiplin kerja terhadap kepuasan kerja karyawan.

\section{Populasi dan Metode Penentuan Sampel}

Populasi dalam penelitian ini adalah jumlah karyawan pada Hotel Le Meridien Bali Jimbaran yaitu 99 orang. Sampel jenuh adalah teknik penentuan sampel bila semua anggota populasi digunakan sebagai sampel. Hal ini sering dilakukan bila jumlah populasi relatif kecil, atau penelitian yang ingin membuat generalisasi dengan kesalahan yang sangat kecil. Istilah lain sampel jenuh adalah sensus (Sugiyono, 2017).

\section{Identifikasi Variabel}

1. Variabel bebas (independent variabel)

2. Variabel terikat (dependent variabl 


\section{Definisi Operasional Variabel}

1. Kepemimpinan $\left(\mathrm{X}_{1}\right)$

Indikator-indikator kepemimpinan terdiri dari :

a) Memiliki motivasi yang kuat untuk memimpin.

b) Tanggung jawab.

c) Disiplin.

d) Mempunyai banyak relasi.

e) Cepat mengambil keputusan.

2. Kompensasi finansial $\left(\mathrm{X}_{2}\right)$

Hotel Le Meridien Bali Jimbaran terhadap kompensasi yang diterima. Indikator-indikator kompensasi terdiri dari :
a) Gaji.
b) Insentif.
c) Tunjangan
d) Fasilitas.

3. Disiplin kerja $\left(\mathrm{X}_{3}\right)$

Disiplin kerja dapat diukur dari indikator, yaitu :
a) Mematuhi semua peraturan perusahaan.
b) Target pekerjaan.
c) Membuat laporan kerja harian.

4. Kepuasan Kerja (Y)
a) Pekerjaan.
b) Upah.
c) Promosi.
d) Pengawas.

Jenis Data yang Diperlukan

1.Berdasarkan Sifatnya

a) Data Kuantitatif

b) Data Kualitatif

2.Berdasarkan Sumbernya

a) Data Primer

b) Data Sekunder

\section{Uji Validitas dan Reliabilitas}

Uji validitas merupakan tingkat keandalan dan kesahihan alat ukur yang digunakan, Reliabilitas adalah suatu alat untuk mengukur suatu kuesioner yang merupakan indikator dari variabel atau konstruk. SPSS memberikan fasilitas untuk mengukur Reliabilitas dengan uji statistik Cronbach Alpha $(\alpha)$. Suatu konstruk atau variabel dikatakan reliabel jika memberikan nilai Cronbach Alpha>0.60.

\section{Teknik Analisis Data}

1. Analisis Kuantitatif

Analisi kuantitatif digunakan untuk menganalisis data yang bersifat bilangan atau berupa angka-angka. Terdiri dari:
a. Analisis Regresi Linier Berganda
b. Uji Asumsi Klasik
c. Analisis Uji F (F-test) 
2. Analisis Kualitatif

Semua perhitungan rumus tersebut di atas akan dibantu pengolahannya dengan Program SPSS for Windows.

\section{HASIL DAN PEMBAHASAN}

\section{Deskripsi Data}

Populasi dalam penelitian ini adalah jumlah karyawan pada PT. Jenggala Keramik Bali yaitu 93 orang. Teknik pengambilan sampel yang digunakan adalah sampel jenuh. Kuesioner terdiri dari 21 pertanyaan, diantaranya 5 pertanyaan untuk variabel Kompensasi Finansial, 5 pertanyaan untuk variabel Kepemimpinan, dan 6 pertanyaan untuk variabel lingkungan kerja fisik, 5 pertanyaan untuk variabel kepuasan kerja. Setiap jawaban mempunyai bobot skor nilai sebagai berikut:

1. Skor $1=$ STS : Sangat Tidak Netuju

2. Skor $2=\mathrm{TS}$ : Tidak Setuju

3. Skor $3=\mathrm{CS}$ : Cukup Setuju

4. Skor $4=S \quad$ : Setuju

5. Skor $5=\mathrm{SS} \quad$ : Sangat Setuju

\section{Uji Validitas dan Reliabilitas Instrumen Penelitian}

1. Hasil Uji Validitas

Ketentuan suatu instrument dikatakan valid atau sahih apabila memiliki koefisien korelasi pearson product moment ( $\mathrm{r}$ ) > 0,3 dengan alpha sebesar 0,05 . Suatu instrumen dikatakan reliable atau handal, apabila memiliki koefisien alpha cronbach $(\alpha)$ lebih besar dari 0,60 (Sugiyono, 2016 : 126).

Tabel 8

Hasil Uji Validitas dan Reliabilitas

\begin{tabular}{|c|c|c|c|c|c|}
\hline Variabel & Iten & $\begin{array}{l}\text { Nilai Pearson } \\
\text { Comelation }\end{array}$ & Ket & $\begin{array}{c}\text { Alpa } \\
\text { Cronbach }\end{array}$ & Ket \\
\hline \multirow[t]{5}{*}{ Kepenimpinan $\left(X_{1}\right)$} & $\mathrm{X} 11$ & 0.556 & Valid & \multirow[t]{5}{*}{0,675} & \multirow[t]{5}{*}{ Reliabel } \\
\hline & $\mathrm{X} 12$ & 0.488 & Valid & & \\
\hline & $\mathrm{X} 13$ & 0.544 & Valid & & \\
\hline & $\mathrm{X} 14$ & 0.602 & Valid & & \\
\hline & $\mathrm{X} 15$ & 0389 & Valid & & \\
\hline \multirow[t]{4}{*}{ Kompensasi finansial $\left(\mathrm{X}_{2}\right)$} & $\mathrm{X} 21$ & 0.776 & Valid & \multirow[t]{4}{*}{0.741} & \multirow[t]{4}{*}{ Reliabel } \\
\hline & $\mathrm{X} 22$ & 0.632 & Valid & & \\
\hline & $\mathrm{X} 23$ & 0.453 & Valid & & \\
\hline & $\mathrm{X} 24$ & 0.677 & Valid & & \\
\hline \multirow[t]{3}{*}{ Disiplin kerja (X3) } & $\mathrm{X} 3.1$ & 0.648 & Valid & \multirow[t]{3}{*}{0.733} & \multirow[t]{3}{*}{ Reliabel } \\
\hline & $\mathrm{X} 32$ & 0.661 & Valid & & \\
\hline & $\mathrm{X} 33$ & 0.630 & Valid & & \\
\hline \multirow[t]{5}{*}{ Kepuasan kerja karyawan (Y) } & Y1 & 0.432 & Valid & \multirow[t]{5}{*}{0.699} & \multirow[t]{5}{*}{ Reliabel } \\
\hline & $\mathrm{Y} 2$ & 0.607 & Valid & & \\
\hline & $\mathrm{Y} 3$ & 0.477 & Valid & & \\
\hline & $\mathrm{Y} 4$ & 0.682 & Valid & & \\
\hline & Y5 & 0.548 & Valid & & \\
\hline
\end{tabular}

Dari hasil diatas dapat disusun persamaan regresi linear berganda sebagai berikut: $\mathrm{Y}=4,553+0,350 \mathrm{X}_{1}+0,229 \mathrm{X}_{2}+0,320 \mathrm{X}_{3}$

\section{Uji Statistik F (F-test)}

Uji ini digunakan untuk mengetahui seberapa besar pengaruh variabel bebas secara bersama-sama atau simultan terhadap variabel terikat (Sujarweni, 2015:162). 
Tabel 19

\begin{tabular}{|c|c|c|c|c|c|}
\hline \multicolumn{6}{|c|}{$\begin{array}{l}\text { Hasil Uji } F \\
\text { ANOVA }^{\circ}\end{array}$} \\
\hline Model & $\begin{array}{l}\text { Sum of } \\
\text { Squares }\end{array}$ & Df & Mean Square & $\mathrm{F}$ & Sig. \\
\hline $\begin{array}{|ll|}1 & \text { Regression }\end{array}$ & 170.825 & 3 & 56.942 & 15.289 & $.000^{4}$ \\
\hline Residual & 353.802 & 95 & 3.724 & & \\
\hline Total & 524.626 & 98 & & & \\
\hline
\end{tabular}

\section{E. PENUTUP}

\section{Simpulan}

Berdasarkan hasil pembahasan yang telah diuraikan, maka simpulan yang diperoleh adalah secara simultan variabel kepemimpinan, kompensasi finansial, dan disiplin kerja, Berpengaruh positif dan signifikan terhadap kepuasan kerja karyawan. Terdapat pengaruh signifikan antara variabel kepemimpinan terhadap kepuasan kerja karyawan pada Hotel Le Meridien Bali Jimbaran. Terdapat pengaruh signifikan antara variabel kompensasi finansial terhadap kepuasan kerja karyawan pada Hotel Le Meridien Bali Jimbaran. Terdapat pengaruh signifikan antara variabel disiplin kerja terhadap kepuasan kerja karyawan pada Hotel Le Meridien Bali Jimbaran. Terdapat pengaruh signifikan antara variabel kepemimpinan merupakan variabel yang memberikan pengaruh dominan terhadap kepuasan kerja karyawan pada Hotel Le Meridien Bali Jimbaran.

\section{Saran}

Berdasarkan simpulan tersebut, maka saran yang dapat diberikan adalah memperhatikan variabel kepemimpinan yang berpengaruh dominan terhadap kepuasan kerja karyawan, terutama pimpinan perusahaan memberikan contoh pentingnya bekerja sama tim dan pentinya untuk memberikan motivasi pada karyawan. Disamping memperhatikan kepemimpinan, manajemen juga harus memperhatikan kompensasi finansial dan disiplin kerja karyawan. Terkait dengan disiplin kerja yang harus mendapatkan perhatian atas hubungan kerja antar karyawan. Sedangkan pada variabel kompensasi finansial, perusahaan sebaiknya memberikan bonus yang menarik bagi karyawan yang sudah menunjukkan dedikasinya, maupun prestasi yang maksimal. Karena masih banyaknya faktorfaktor yang mempengaruhi kepuasan kerja karyawan, diharapkan peneliti berikutnya menambah variabel variabel bebas yang mempengaruhi kepuasan kerja karyawan sehingga diharapkan mendapatkan data yang lebih akurat dan mendekati keadaan sebenarnya. 


\section{DAFTAR PUSTAKA}

Afandi P. (2018). Manajemen Sumber Daya Manusia; Teori Konsep dan Indikator (Pertama). Zanafa Publishing, Riau.

Feriyanto, A., \& Shyta Triana, E. (2015). Pengantar Manajemen (3in1) untuk mahasiswa dan umum (Pertama). Mediatera, Yogyakarta.

Marwansyah. (2014). Manajemen Sumber Daya Manusia (Kedua). Alfabeta,CV - Bandung.

Sudarmini, K., dan Putu, P. . (2018). Pengaruh Kompensasi dan Kepuasan Kerja terhadap kinerja karyawan pada La Favela Restaurant di Seminyak, Kuta. Jurnal Manajemen Warmadewa, 17(1).

Sugiyono. (2017). Metode Penelitian Kuantitatif, Kualitatif, dan R\&D (Kedua). Penerbit Alfabeta, Bandung.

Sujarweni, .W.P. (2015). Metodelogi Penelitian Bisnis \& Ekonomi Y. Pustaka Baru Press (ed.); Pertama).

Sutrisno, E. (2017). Manajemen Sumber Daya Manusia (Kedua). Penerbit Kencana, Jakarta. http://bali.bps.go.id(2019) Badan Pusat Statistik 